\title{
Dennis Scheller-Boltz (ur.) (2015). New Approaches to Gender and Queer Research in Slavonic Studies. Wiesbaden: Harrassowitz Verlag
}

New Approaches to Gender and Queer Research in Slavonic Studies višejezični je zbornik koji sadržava 29 članaka utemeljenih na izlaganjima predstavljenima na međunarodnoj konferenciji »Language as a Constitutive Element of a Gender Society - Developments, Perspectives and Possibilities in the Slavonic Languages « održanoj na Sveučilištu u Innsbrucku u listopadu 2014. godine. Riječ je o skupu prominentnih lingvističkih imena koji predstavlja treću u nizu od tri uspješne međunarodne konferencije usmjerene na promociju i poticanje razvoja slavenske rodne lingvistike, osobito izvan slavenskoga jezičnog područja. Prva takva konferencija održana je 2001. na Sveučilištu u Jeni pod nazivom »Gender - Sprache - Kommunikation - Kultur«, a slijedila je »Doing Gender - Doing the Balcans« 2011. godine na Humboldtovu sveučilištu u Berlinu. S obzirom na duže razmake između konferencija treba uzeti u obzir činjenicu da u tim razdobljima dolazi do značajnih promjena u poimanju rodnoga pitanja u lingvistici. Upravo zato ovaj zbornik predstavlja bitan doprinos novomu pogledu na fenomen roda i rodnoga identiteta unutar kojega se sve više osvještava činjenica da oni nisu fiksirani i nepromjenjivi entiteti te da je rodno pitanje u lingvistici mnogo više od fokusiranja isključivo na ženu ili odnos žene i muškarca u jeziku. Propitivanjem roda i rodnih identiteta u pitanje se dovodi njihovo mjesto u rigidnome binarnom sustavu, što dovodi do kritike heteronormativnosti i sasvim nove perspektive današnjih queer istraživanja. Svakako treba istaknuti i potrebu interdisciplinarnosti u istraživanjima ovoga tipa s obzirom na to da isključivo lingvistička analiza, kao što je dosad više puta dokazano, ne može donijeti bitne pomake i značajnije rezultate. Stoga je i cilj spomenute konferencije bio proširiti pogled na slavensku rodnu lingvistiku kroz nove pristupe rodnomu pitanju u slavenskim jezicima, predstaviti neslavenskomu lingvističkom svijetu specifičnosti istraživanja rodne problematike u slavenskim jezicima te potaknuti znanstvenike koji se bave slavenskim jezicima na implementaciju spoznaja rodnih $\mathrm{i}$ queer istraživanja neslavenskih jezika.

Prvu tematsku cjelinu zbornika čine tri članka koja predstavljaju opći pregled slavenskih rodnih istraživanja. Alla Kirilina, najistaknutije ime ruske rodne lingvistike danas, fokusira se na semiotički aspekt prezentacije roda u postsovjetskoj Rusiji te analizira ideologije koje se očituju u ruskome diskursu i izravno utječu na percepciju roda i rodnoga identiteta u ruskoj kulturi. Pritom ističe dvije glavne i ujedno međusobno suprotstavljene tendencije: 1) trend eliminacije rodne asimetrije i 2) trend reanimacije i jačanja starih patrijarhalnih stereotipa. Tendencija eliminacije rodne asimetrije ilustrirana je primjerima rodne ekspertize tekstova, institucionalizirane primjene novih normi u pravnim tekstovima, javnome internetskom diskursu i osobnim dokumentima ili, primjerice, zamjene ruskih rodno neutralnih leksema kalkovima iz engleskoga jezika svojstvene medijskomu diskur- 
su koja zapravo dovodi do suprotnoga i nepoželjnoga efekta jačanja rodnih razlika. Tendencija reanimacije i jačanja patrijarhalnih stereotipa predstavljena je primjerima pseudoznanstvenih tekstova mizoginoga sadržaja, medijskoga predstavljanja žene kao potrošača i seksualnoga objekta $\mathrm{i}$ jačanja religijske propagande. Heiko Motschenbacher u svojemu članku ističe potrebu usklađivanja strukturalističkih rodnih istraživanja s poststrukturalističkom istraživačkom metodologijom s obzirom na to da sinergija tih dvaju pristupa može dati značajne rezultate u istraživanju odnosa jezika, roda i identiteta. Pokazuje se to ilustracijom načina na koji diskurzivni pristup u okviru strukturne rodne lingvistike uz pomoćleksičko-gramatičkih i pragmatičkih analiza pridonosi deesencijalizaciji roda. Kao predmet analize uzimaju se imenice hrvatskoga jezika kojima se imenuju osobe, a provedena analiza pokazuje da je relativno malen broj takvih imenica u skladu s normativnim, strogo rodno binarnim linijama koherencije. Pritom primjeri odstupanja od tih linija koherencije svjedoče o tome kako rod čak ni na strukturnoj jezičnoj razini ne funkcionira kao homogen fenomen, već je uvjetovan sociokulturološki i manifestira se kroz složene rodne diskurse. Jiřina van Leeuwen-Turnovcová problematizira rod i rodne uloge u odnosu na društvenu stratifikaciju i načine ponašanja koji su socijalno, kulturološki i mentalno specifični u rodnome kontekstu. Njezino je stajalište da rodne ideje i uloge nisu određene isključivo samim konceptom roda već u velikoj mjeri i društvenim položajem pojedinca te mjerom u kojoj mu je dostupno obrazovanje i mogućnost napredovanja u društvenoj hijerarhiji. Pritom autorica naglašava kako treba uzeti u obzir razlike koje postoje između društava i kultura srednjoeuropskih $i$ istočnoeuropskih zemalja u načinu na koji stvaraju svoj vlastiti identitet uslijed različita kulturno-povijesnoga razvoja.

Sljedeća tematska cjelina donosi članke koji se bave rodnom problematikom na primjeru nekoga od južnoslavenskih jezika. Ursula Doleschal u svojemu članku donosi uvid u aktualno stanje slovenskih rodnih istraživanja u lingvistici te predstavlja način na koji su žena i muškarac oslikani u slovenskome jeziku fokusirajući se na gramatičke strukture. Autorica na taj način pokazuje kako slovenski jezik ima vrlo visok potencijal za rodno specifičnu denotaciju osoba, a gotovo nikakav za rodno neutralnu. Upravo mogućnost da se žena učini »vidljivom « u jeziku glavni je razlog jedinstvenoga statusa slovenskoga u odnosu na druge slavenske jezike. U prilogu Saške Štumberger ilustriraju se promjene u društvenome položaju žena u slovenskome društvu kroz analizu rječnika neologizama slovenskoga jezika koji je izašao 2012. godine pod nazivom Slovar novejšega besedja slovenskega jezika. Na primjeru leksema koji se odnose na osobine, djelatnosti, zanimanja i funkcije žene pokazano je kako se promijenilo semantičko i pragmatičko značenje sufikasa kojima se upućuje na osobu ženskoga spola. Zbog toga se danas takve imenice u slovenskome jeziku mogu upotrebljavati s neutralnom referencijom, što svjedoči o bitno drugačijemu položaju žene u odnosu na muškarca u slovenskome društvu općenito. Simona Rajilić upotpunjava prikaz rodnih istraživanja u južnoslavenskim jezicima člankom o seksističkim praksama u srpskome jeziku i antiseksističkim alternativa- 
ma predloženima od strane feminističkih lingvistkinja i aktivistkinja s ciljem uklanjanja ustaljene prakse »nevidljivosti« žena u jeziku. Međutim, autorica naglašava da je navedeni problem znatno širi od jezične prakse upotrebe imenica muškoga gramatičkog roda za označavanje osoba ženskoga roda te predstavlja neke od uputa za rodno osjetljivu i nediskriminacijsku upotrebu jezika. U članku Roswithe Kersten-Pejanić predstavljena su različita pitanja povijesnih i aktualnih rasprava o generičkome muškom rodu u hrvatskome jeziku. Iako se pitanje upotrebe muških gramatičkih oblika leksema kao rodno neutralne prakse u rodnoj lingvistici danas smatra već pomalo zastarjelim, autorica navodi obilje duboko ukorijenjenih i konvencionaliziranih primjera takve prakse u hrvatskome jeziku zbog kojih to pitanje i danas možemo smatrati aktualnim. Josipa Kovačevići Maja Opašić također se bave rodnom problematikom u hrvatskome jeziku. Predmet njihova interesa jest frazeološka razina jezika, a rodno obilježenim frazemima hrvatskoga jezika pristupaju kroz kontrastivnu analizu s njihovim engleskim ekvivalentima. Analizirana građa dijeli se na skupinu frazema koji svojim sastavnicama upućuju isključivo na jedan spol i skupinu frazema koji se mogu odnositi na oba spola, a rezultati analize pokazuju kako su frazemi prve skupine najčešće motivirani određenim spolnim ili rodnim stereotipima. Upravo se zbog toga hrvatski i engleski rodno obilježeni frazemi u velikoj mjeri podudaraju, a nepodudarnosti među njima upućuju na specifičnosti jezika i kulture kojoj pripadaju.

Istočnoslavenski jezici također su zastupljeni u zborniku i predmet su rodnih istraživanja predstavljenih u zasebnoj tematskoj cjelini. Maksim Krongauz predstavlja rodne paradigme sufikasa u ruskome jeziku s pomoću kojih se ostvaruje referencija na muški ili ženski spol. U skladu sa svojim strogo strukturalističkim pristupom autor pokazuje kada jest, a kada nije moguće u suvremenome ruskom jeziku upotrebljavati mocijske sufikse te navodi semantička ograničenja za upotrebu sufikasa koji bi učinili ženu »vidljivijom« u jeziku i zaključuje kako je riječ o jezičnoj praksi koja je u suvremenome ruskom jeziku još uvijek izuzetno rijetka. Brian Baer zauzima dijametralno suprotan stav u članku koji problematizira tradicionalne vrijednosti i heteronormativne identitete te daje poticaj ruskim rodnim $\mathrm{i}$ queer istraživanjima. U članku se fokusira na razvoj ruskoga diskursa o homoseksualnosti od 1993. do 2013. godine te usmjerava pažnju čitatelja na lekseme korištene $u$ analiziranome diskursu. Pritom pokazuje kako se u promatranome razdoblju mijenjala učestalost u upotrebi leksema iz prikupljenoga korpusa, navodi neologizme koji su se pojavili u ruskome jeziku i upućuje na promjene semantičkoga i pragmatičkoga aspekta značenja pojedinih leksema. Dennis Scheller-Boltz i Mathias Althaler svoj prilog rodnoj problematici daju člankom u kojemu se analizira jedan talk show na ruskoj televiziji od 2013. godine kao primjer načina na koji se o homoseksualnosti raspravljalo u vrijeme stupanja na snagu zakona o anti-gay propagandi. Kao što je analiza pokazala, cilj spomenutoga zakona nije bilo samo sprečavanje tzv. netradicionalnoga načina života već je osim toga trebao promovirati i učvrstiti jedinstveni ruski identitet utemeljen na tradicionalnim moralnim vrijednostima i 
rodnim ulogama. Autor smatra kako se takav pokušaj reguliranja seksualnosti ruskoga stanovništva opravdavao potrebom za povećanjem stope nataliteta koja bi osigurala opstanak i nadmoć ruske nacije. Sličan stav i zaključke donosi i članak Dennis Scheller-Boltz u kojem se analizira medijski diskurs kojim je popraćena pobjeda Conchite Wurst na natjecanju za Pjesmu Eurovizije 2014. kako bi se pokazalo na koji se način instrumentaliziraju rodni identiteti s određenom svrhom. Kroz analizu se očitovalo da apeliranje na heteronormativnost nije samo homofobna strategija korištena u pokušaju promicanja tradicionalnih vrijednosti, klasičnih rodnih predodžbi i patrijarhalne socijalne strukture već i oruđe kojim se teži ponovo ustoličiti patriotizam i sačuvati rusku naciju. U sljedećemu članku Katharina Klingseis ispituje na koji način odjeća, vanjski izgled i posao utječu na formiranje rodnoga identiteta čovjeka. Autorica daje pregled feminističkih i lingvokulturoloških teorija o odnosu odjeće i roda, a zatim te teorijske postavke uspoređuje s realnim, svakodnevnim predodžbama Ruskinja i Rusa. Analiza pokazuje koliko društveni diskurs i stereotipi utječu na rodni identitet. Olena Levčenko svoj članak posvećuje rodnim poredbama u diskursu ukrajinske proze s ciljem da pokaže kako se u njima stvara konceptualna i jezična slika svijeta suvremene žene i muškarca. Cilj je njezine analize dobiti preliminarne rezultate o razlikama u jezičnoj slici svijeta žena i muškaraca, istražiti njihove vrijednosne orijentacije i odrediti stupanj njihove jezične kreativnosti kao polazišnu točku za daljnja rodna istraživanja. Ukrajinski jezik kao predmet rodne analize promatra i Christina Pirs'ka u članku u kojem analizira metafore u suvremenome ukrajinskom književnom diskursu fokusirajući se na nacionalne, kulturološke i rodne osobitosti. Pritom iz građe prikuplja različite metaforičke i strukturno-semantičke modele koji ukazuju na to da žene i muškarci upotrebljavaju različite metafore.

Sljedeća tematska cjelina odnosi se na rodna istraživanja u zapadnoeuropskim jezicima. Jana Valdrová postavlja pitanje može li se u češkome jeziku govoriti o feminističkoj lingvistici. Autorica čitatelja upoznaje s teškoćama na koje je u svojem nastanku nailazila feministička lingvistika te o nedostatku orijentacije koja otežava njezin razvoj. Na temelju različitih lingvističkih eksperimenata povezanih s asocijacijama i spoznavanjem također upućuje na rodne ideje i rodne stereotipe i pokazuje kako su duboko ukorijenjeni u češkome društvu i jeziku. Marek Łaziński pokazuje kako je leksem gender ušao u diskurs poljskoga jezika i kako se njegovo poimanje unutar poljskoga društva mijenjalo kroz godine analizirajući način na koji se spomenuti leksem leksikografski bilježi i obrađuje. Na temelju toga na kraju članka kao svojevrstan zaključak daje i vlastiti prijedlog njegove leksikografske obrade. Mariola Majnusz-Stadnik bavi se konceptom žene i ženskosti u frazemima poljskoga jezika. Na primjeru frazema sa sastavnicama kobieta, baba, dziewka, dziewczyna, dama, niewiasta i białogłowa analizira način na koji se na frazeološkoj razini jezika odražavaju rodni stereotipi.

Sljedeća tematska cjelina objedinjuje nekoliko članaka posvećenih rodnim pitanjima koja možemo smatrati interlingvističkima. Ingeborg Ohnheiser posvećuje 
članak javnim debatama i publikacijama o rodnim pitanjima u Austriji, Češkoj, Rusiji, Ukrajini i Bjelorusiji ističući slične lingvističke i ekstralingvističke strategije i argumente u korist ili pak protiv rodno osjetljive upotrebe jezika. Autorica osobito naglašava da nacionalni identitet pritom ponekad ima značajnu ulogu vidljivu u potrebi razlikovanja jednoga nacionalnog diskursa od drugoga kao što je to primjer ukrajinskoga i bjeloruskoga u odnosu na ruski. Claudia Posch svojim člankom nadopunjava prethodni jer detaljno analizira strukturu argumenata i argumentacijskih strategija upotrijebljenih u austrijskome diskursu od strane kritičara rodno specifične i nediskriminirajuće upotrebe jezika. Članak Elene Graf pridonosi slavenskoj rodnojlingvistici putem određenih sociolingvističkih spoznaja. Na primjeru ruskih i poljskih reklama autorica ilustrira dinamiku rodnih stereotipa pokazujući kako se upotrebljavaju i reproduciraju u jeziku, što dovodi do seksizma i diskriminacije.

Posljednja tematska cjelina donosi članke koji rodna pitanja promatraju u okvirima kulturologije, književnosti ili sociologije. Ol'ga Ključko i Ljubov' Štyleva bave se analizom tradicionalnih vrijednosti u rodnoj socijalizaciji i suvremenome ruskom obrazovanju te smatraju da upravo one čine temelj za način života u skladu s tradicionalnim poimanjem roda, identiteta i društva u cjelini. Pritom ističu da u današnje vrijeme globalizacije i promicanja različitih rodnih ideja samo tradicionalne vrijednosti osiguravaju heteronormativnost rodne socijalizacije i tradicionalne rodne uloge. Piotr Sobolczyk analizira odnos suvremene poljske Crkve prema homoseksualnosti i neheteronormativnim identitetima. Kao zaključak mu se nameće činjenica da homoseksualnost egzistira u svojevrsnoj napetosti između Crkve i društva te između prihvaćanja i odbacivanja, što u velikoj mjeri određuje način života homoseksualnih i neheteronormativnih osoba u Poljskoj. U svojemu drugom članku isti autor bavi se pitanjem dosad neopisanoga oblika Campa ${ }^{1}$ koji funkcionira kao osobiti lokalni fenomen na području zemalja srednje i istočne Europe. Uz osvrt na tekstove Mirona Białoszewskog, Grzegorza Musiała i Michała Witkowskog usredotočuje se na visoki i niski te naivni i svjesni Camp i demonstrira ispreplitanje različitih oblika Campa u kapitalističkoj ekonomiji koja je bila u oštrome kontrastu prema njihovu statusu u socijalističkim vremenima. Andrea Zink u svojemu članku daje uvid u svijet queer muškaraca u romanu Nikolaja Gogolja Mёртвые души (Mrtve duše). Autorica izdvaja mehanizme kojima Gogolj dekonstruira rod i prevladava normu heteroseksualnosti. Njezin queer pristup analizi muških likova u analiziranome romanu temelji se na teoriji Judith Butler te otkriva slabosti heteronormativnosti i ističe nejasne i promjenjive granice između heteronormativnosti i neheteronormativnosti. Bianca Blum analizira odabrane ruske priručnike namijenjene obrazovanju djevojaka u 19. stoljeću s ciljem da opiše predodžbu o ženskosti u ruskome aristokratskom društvu toga doba. U radu ilustrira

1 U značenju engleskoga termina camp kao senzibiliteta i kulturnoga koncepta u hrvatskome se jeziku upotrebljavaju različiti leksemi i sintagme te u znanstvenome diskursu koji se bavi tim fenomenom nalazimo varijante Camp, kemp, camp registar, camp okvir i sl. U ovome prikazu upotrebljava se termin Camp pisan velikim slovom s obzirom na to da ga u tome obliku nalazimo u naslovu znanstvene monografije Sanje Muzaferije »Od kiča do Campa: strategije subverzije«. 
i načine na koje se te predodžbe primjenjuju i transformiraju u književnosti. Christine Engel analizira ruski film Opдa (Horda) režisera Andreja Proškina i scenarista Jurija Arabova, jednoga od najpopularnijih suvremenih ruskih scenarista, te ga dovodi u vezu s knjigom Danila Andrejeva Роза Мира (Ruža svijeta). Razmatrajući rodne ideje i rodne uloge, autorica pokazuje koliko su duboko tradicionalne predodžbe o ženskosti ukorijenjene u ruskome društvu. Erika Kegys bavi se tzv. sovjetskim modelom ženskosti i analizira kako su i koliko te ideje utjecale na mađarsko društvo i predodžbu o ženskosti u razdoblju između 50 -ih i 70 -ih godina prošloga stoljeća.

Svi radovi sadržani u ovome zborniku zorno ilustriraju svu različitost slavenskih rodnih i queer istraživanja. Kroz različite teme i pristupe zastupljeno je sedam slavenskih jezika, a rezultati provedenih analiza predstavljaju velik potencijal za sva buduća poredbena istraživanja rodne problematike u slavenskoj lingvistici. Treba primijetiti da spoj rodnih i queer istraživanja različitim pristupima obogaćuje pogled na odnos roda i slavenskih jezika, a potpuno opravdana zastupljenost književnih i kulturoloških rodnih tema u zborniku upućuje na interdisciplinarnost kao jedini legitiman način na koji se može cjelovito pristupiti jezičnomu izrazu fenomena roda i identiteta.

Anita Hrnjak 